\title{
Calcified root cells in Miocene pedogenic carbonates of the Madrid Basin: evidence for the origin of Microcodium $\mathrm{b}$
}

\author{
Ana M. Alonso-Zarza ${ }^{\mathrm{a},{ }^{*}}$, M. Esther Sanz ${ }^{\text {a }}$, Jose P. Calvo ${ }^{\text {a }}$, Pilar Estévez ${ }^{\mathrm{b}}$ \\ "Departamento Petrología y Geoquímica, Facultad de Ciencias Geológicas, Universidad Complutense, Madrid 28040, Spain \\ ${ }^{h}$ Departamento Biología Vegetal J, Facultad de Ciencias Biológicas, Universidad Complutense, Madrid 28040, Spain
}

\begin{abstract}
Calcified root cells, forming microspar and pseudospar mosaics of calcite and/or dolomite crystals, constitute a major component of calcretes and dolocretes from the Miocene of the Madrid Basin. The calcified cells occur in massive nodules or fill root tubes in the calcrete-dolocrete profiles. The arrangement of the cells within the mosaics and their internal features, together with the isotopic data, clearly indicate that the crystals formed through the calcification of root cells and not through recrystallization or dolomitization. Calcified root cells formed in a favourable microenvironment caused by biochemical phenomena associated with plant growth. In these examples, the calcification is incomplete as only in the innermost part of the root the cells were totally calcified, whereas in the root cortex only the cell walls were calcified. The distribution of the calcified cells within the roots was controlled by the different ionic environments which prevail within an active root system. In the inner part the ionic conditions were mostly controlled by the cellular activity of the root creating a suitable microenvironment for the biomineralization of the cells. This differs notably from most published examples of calcified root cells in which it is usual for the cortical cells of roots to be completely calcified. The calcified root cells of the Madrid Basin resemble unequivocally the problematic Microcodium (b), which suggests that this type of Microcodium formed through calcification of root cells. (c) 1998 Elsevier Science B.V. All rights reserved.
\end{abstract}

Keywords: palaeosols; calcified root cells; biomineralization; Microcodium; Madrid Basin

\section{Introduction}

The presence of root structures in sedimentary strata is indicative of terrestrial conditions and proximity to subaerial exposure surfaces (Klappa, 1978). Their recognition, therefore, is of critical importance in basin analysis and palaeoenvironmental determination. Such structures, usually located in palaeosols, can also provide insight into the distribution and

\footnotetext{
$\bar{*}$ Corresponding author. Fax: +34 (1) 544-2535; E-mail: alonsoza@eucmax.sim.ucm.es
}

evolution of ancient plant communities (Retallack, 1990). Root structures such as rhizoliths (Klappa, 1980) and/or rhizocretions (Calvet et al., 1975) are relatively easy to recognize in the ancient record. The activity and presence of roots, however, can also be indicated by the occurrence of calcified root cells. Recent experimental work by Jaillard (1987) and Jaillard et al. (1991), for example, has demonstrated that calcification of root cells can result in the formation of massive calcite crystalline mosaics. Calcite crystals attributed to mineralization of root cells have been recognized in ancient (Klappa, 1978) 
and recent soils (Ducloux and Butel, 1983; Jaillard, 1987). The identification and interpretation of the calcified root cells, however, is difficult because they may form massive calcite and/or dolomite mosaics that are similar to neomorphic mosaics and to the spheroidal dolomites (Gunatilaka, 1989) that are found in ground-water dolocretes (Spötl and Wright, 1992).

In this paper we describe calcite and dolomite mosaics from Miocene pedogenic carbonates of the Madrid Basin, Central Spain (Fig. 1), that are interpreted to be a result of calcification of cells of roots. In addition, the calcified root cells are compared with Microcodium (b) of Esteban (1972), named type-3 by Plaziat (1984).

The role of roots in forming Microcodium and in contributing to 'rhizolite' calcretes is the subject of current debate (Wright et al., 1995) as witnessed by discussions of Verrecchia et al. (1995) and replies of Wright et al. (1996) and Verrecchia et al. (1996). This study does support the idea that many calcretes are, or contain, the products of extensive root calcification and this produces fabrics that resemble forms of Microcodium.

\section{Techniques and methods}

Previous studies carried out by Alonso et al. (1986) and Calvo et al. (1986), allowed us the selection of 30 different palaeosol profiles to be analysed in detail as they contained micro- and pseudospar mosaics. More than 60 thin-sections were analysed under transmitted light microscope and about 15 under the cathodoluminscope (CL) (Technosyn). Scanning electron microscopy was carried on a JEOL 6.400 working on $20 \mathrm{kV}$, fracture surfaces were covered with gold, whereas polished ones were covered with carbon to use backscattered electrons. Mineralogy of the samples was determined using a Philips XRD system operating at $40 \mathrm{kV}$ and $30 \mathrm{~mA}$ with a Monochromated $\mathrm{CuK}_{\alpha}$ radiation.

\section{Geological and palaeoenvironmental setting}

The material analysed in this paper occurs within Miocene deposits of the northern area of the Madrid Basin in Central Spain (Fig. 1). The basin and its sedimentary infilling have been studied by several au- thors as regards their stratigraphic (Junco and Calvo, 1983) and detailed sedimentological aspects (Calvo et al., 1989; Alonso Zarza et al., 1992; Sanz et al., 1995). The basin is filled by continental sediments ranging in age from Palaeogene to Pliocene. The sediments described in this paper occur in the so-called Miocene Intermediate Unit (Fig. 1B), which was deposited in a mosaic of environments including lacustrine, palustrine, fluvial and alluvial fan (Fig. 1C, Fig. 2).

In the northem area, where this study was carried out, the Intermediate Unit is formed of two different sequences (Alonso et al., 1986) (Fig. 2). The lower sequence has a maximum thickness of $50 \mathrm{~m}$. It comprises a complex succession from medial alluvial fan in the northernmost area to lake deposits to the south. The alluvial fan sediments consist of coarse arkosic sands, fine loose gravels, and brown clays. They are organized in fining-upward sequences of about $2 \mathrm{~m}$ thick in which more than $1.5 \mathrm{~m}$ are formed by arkosic sands. Towards the south, grain size progressively decreases and fine arkoses and brown clays are the dominant lithofacies. Composition of the brown clays is varied and comprises illite, smectite, and also sepiolite. Calcrete and dolocrete beds up to $1.2 \mathrm{~m}$ thick are commonly intercalated at the top of the sequences. In some areas, several vertically stacked calcrete and/or dolocrete profiles may occur. Calcrete and/or dolocrete are the most characteristic facies of the transition between the arkosic alluvial fans and the lake environment and are present on a narrow belt, about $1-1.5 \mathrm{~km}$ wide between the fan and the nearby lake margin (Calvo et al., 1989). Both calcretes and dolocretes are locally replaced by nodular chert. This sequence grades laterally into lake margin deposits (Calvo et al., 1989) composed of green $\mathrm{Mg}$-smectite-rich clays, palustrine nodular dolostones and, locally, sepiolite beds. The upper sequence (Alonso et al., 1986) consists of $60 \mathrm{~m}$ of loose gravel and coarse arkosic sand with minor clays. These lithofacies are arranged in fining-upward sequences up to $2.5 \mathrm{~m}$ thick. Calcrete and dolocrete profiles are not present in this area within the upper sequence, whose occurrence as coarse arkoses on distal and lake deposits of the lower unit indicates a progradation of the alluvial systems sourced from the Central System (Figs. 1 and 2). 

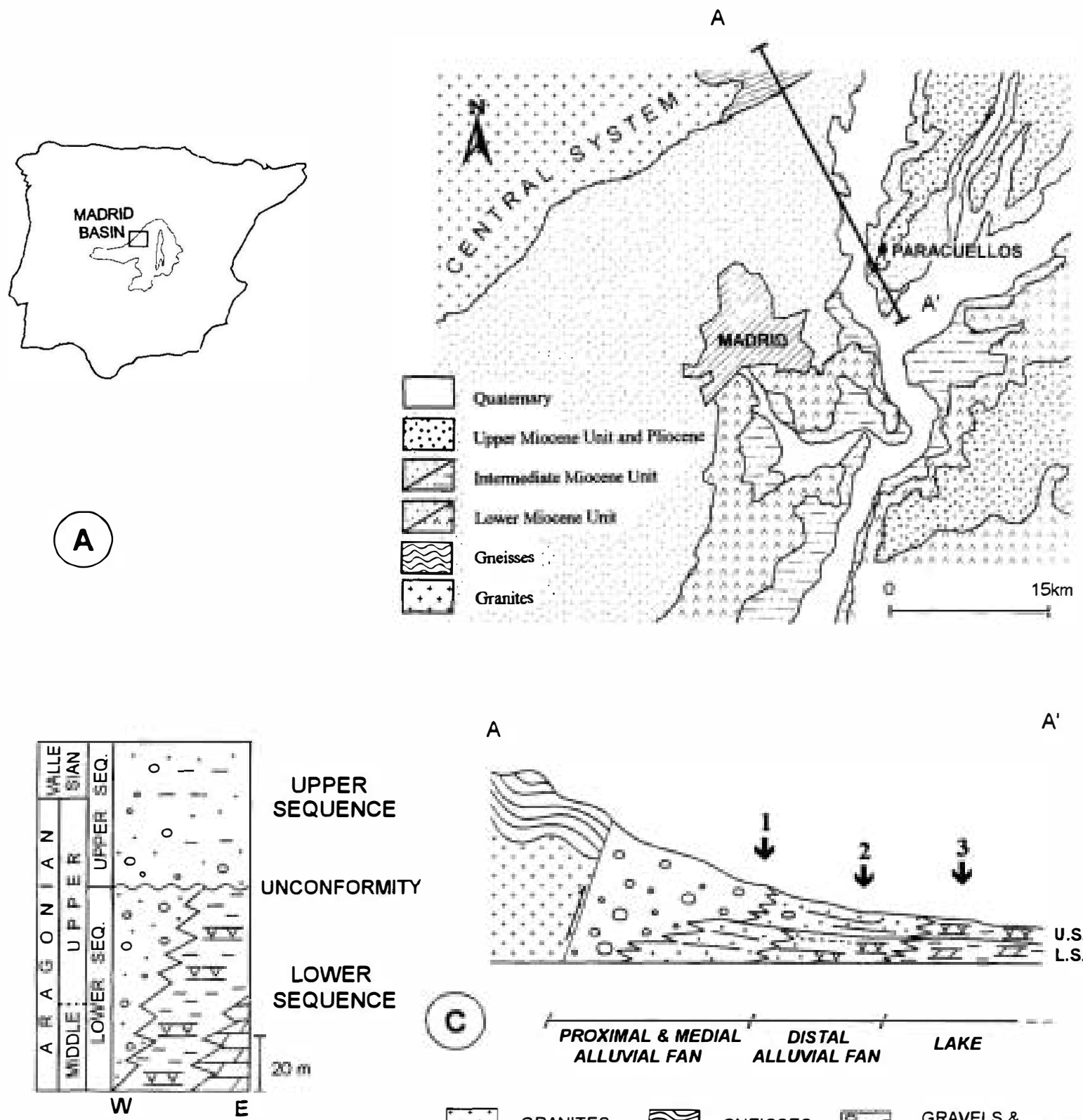

A

$A^{\prime}$

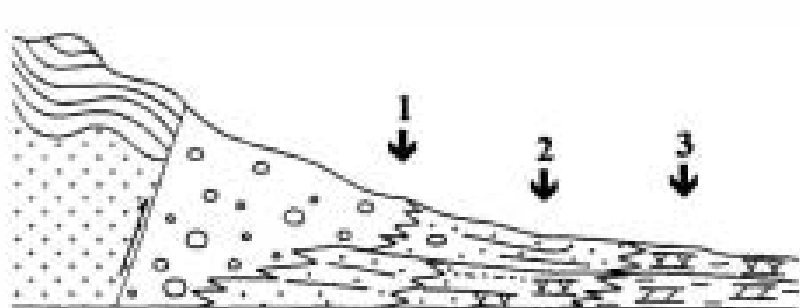

U.S.
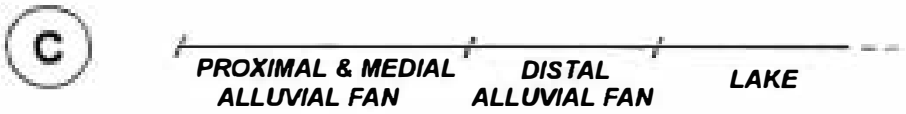

GRANITES GNEISSES \%O GRAVELS \&

COARSE ARKOSES
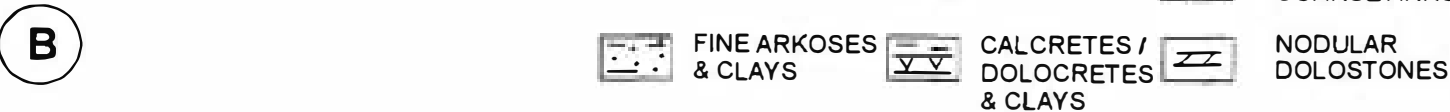

Fig. 1. Geological setting. (A) Geologic map of the Paracuellos de Jarama area (boxed on the sketch for location in the Madrid Basin). (B) Stratigraphy of the Miocene deposits (Intermediate Unit) in the Paracuellos de Jarama area. (C) Sketch of the facies distribution along section $A-A^{\prime}$ of (A). 1,2 and 3 refer to the sedimentary logs of Fig. 2. 

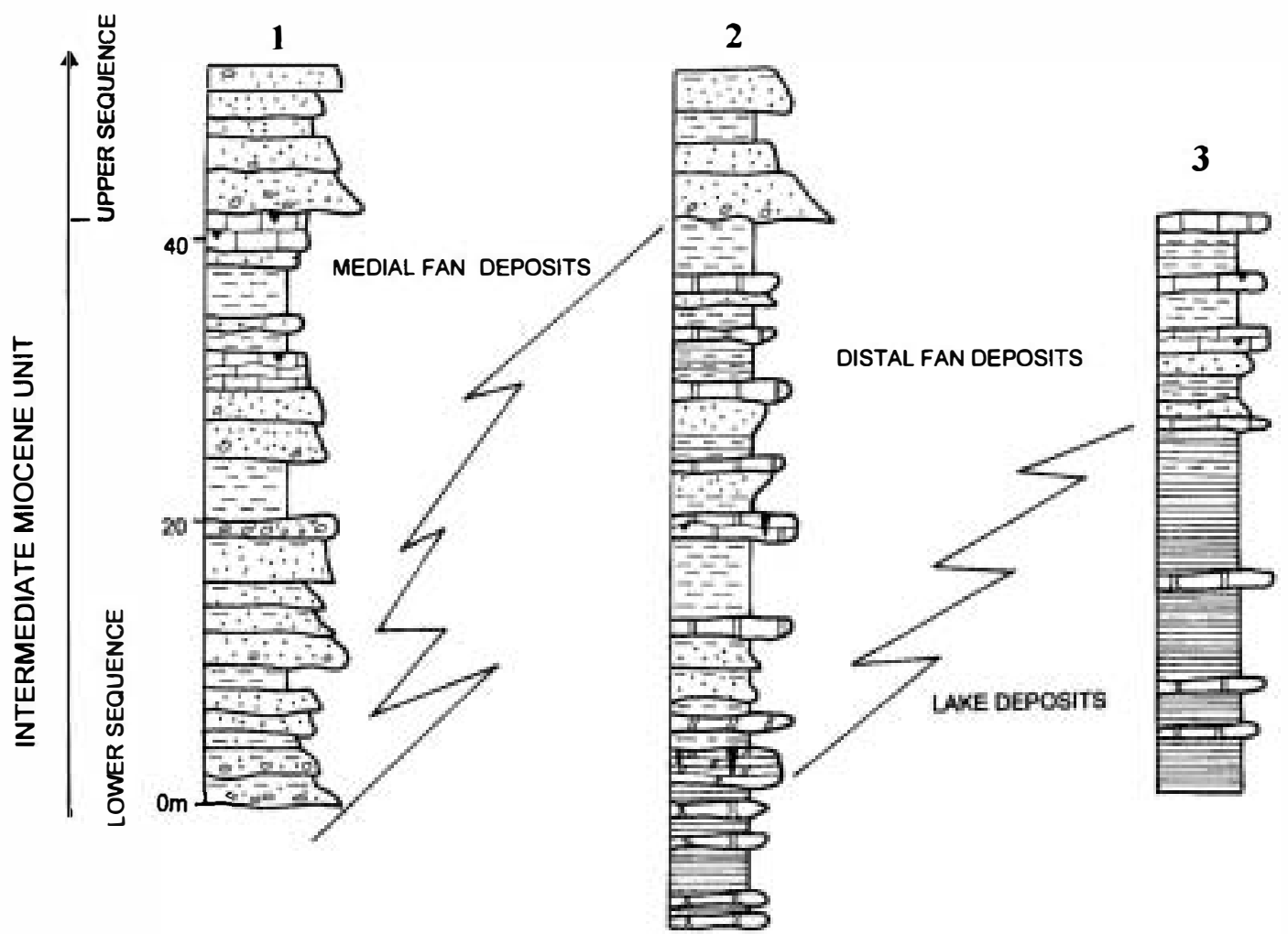

\begin{tabular}{|c|c|}
\hline 00 & Gravels \\
\hline & Sands. Arkoses \\
\hline & Brown Clays \\
\hline$\square$ & Green Clays \\
\hline
\end{tabular}
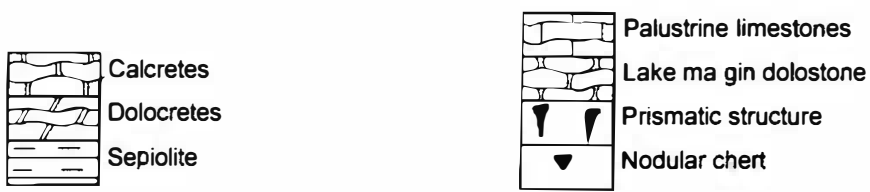

Fig. 2. Sedimentary logs of the Miocene of the Paracuellos de Jarama area illustrating the transition between alluvial fan and lacustrine deposits. Location of sections 1, 2 and 3 is shown in Fig. 1C. Calcretes and dolocretes are located preferably within distal fan facies. Only the lowermost deposits of the upper sequence have been represented.

\subsection{Calcretes and dolocretes of the northern area of the basin}

As aforementioned, calcretes and dolocretes are best developed in the lower sequence of the intermediate unit (Fig. 2). The distribution of calcite and dolomite shows a clear sedimentological trend. Dolocretes were typically developed closer to the lake margin area, whereas calcretes reflect environments not influenced by the lake margin (Calvo et al., 1995). Locally, both dolomite and calcite are present within the same soil profile. More than 30 different calcrete-dolocrete profiles occur in the study area, mostly concentrated in distal fan facies (Fig. 2). All of them have been carefully analysed, although they only show slight variations in mineralogy, thickness, and microfabric.

The individual calcrete-dolocrete profiles (Figs. 3 and 4) average $1.5 \mathrm{~m}$ in thickness. They are developed on brown clays and occasionally on fine arkoses. The complete profiles consist, from bottom to top, of three horizons: bioturbated and rooted clays, prismatic, and platy horizons (Fig. 3). The lower clays are formed of smectite, illite, and minor analcime. Calcified roots or rhizoliths are preserved as vertical and horizontal tubes of about $4 \mathrm{~mm}$ in width and $4 \mathrm{~cm}$ in length. They are usually formed of white calcite and dolomite that consist of micrite 

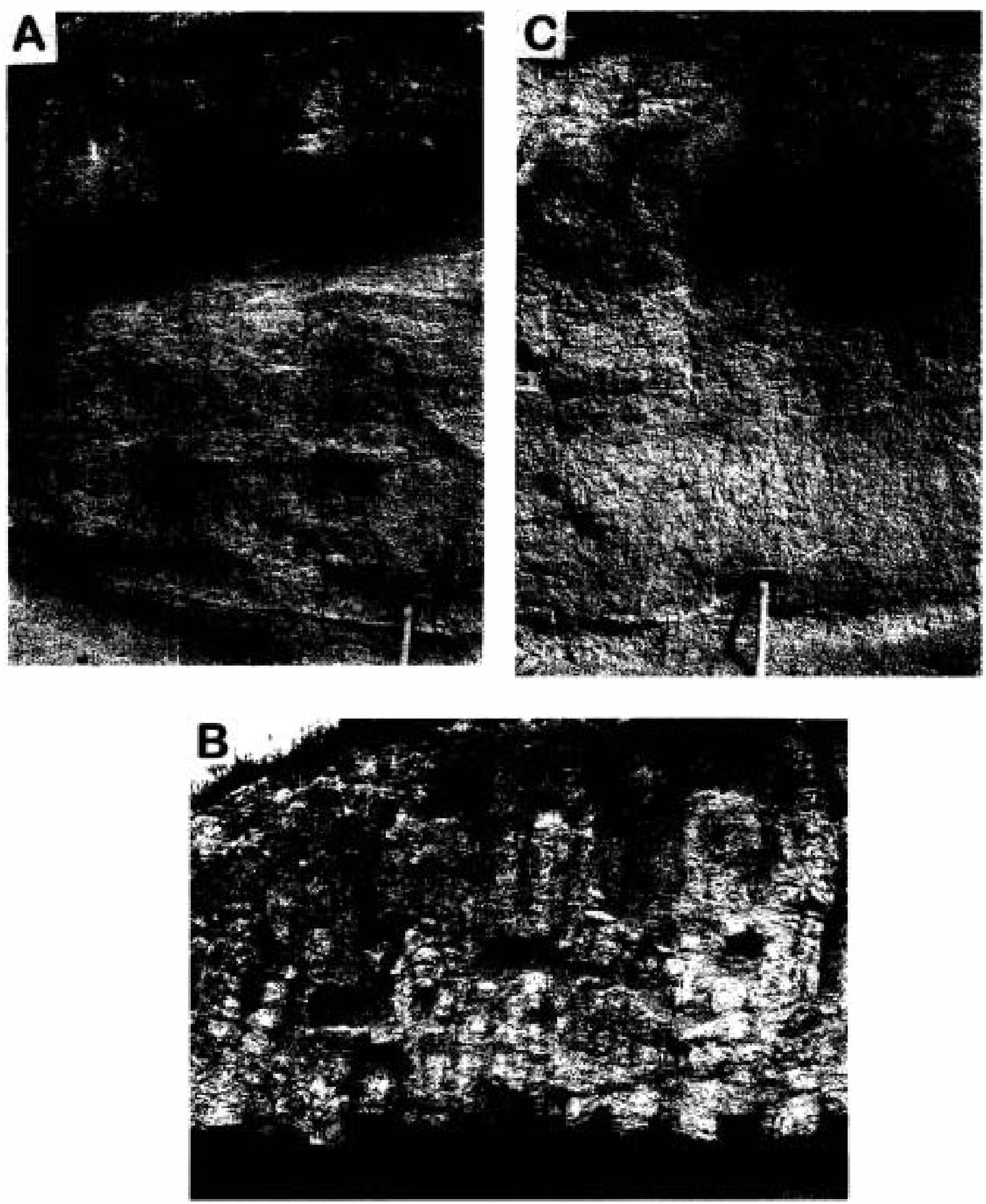

Fig. 3. Typical calcrete--dolocrete profiles. (A) Calcrete profile formed by two horizons: bioturbated clays with abundant white veins (arrowed) that consist of microspar and pseudospar mosaics. The harder part of the profile corresponds to the prismatic horizon. (B) Close-up view of a typical prismatic horizon. Diameter of the lens cap is $8 \mathrm{~cm}$. (C) Dolocrete profile showing the three horizons, although the platy one, at the top, is relatively thin. Hammer for scale is $30 \mathrm{~cm}$. 


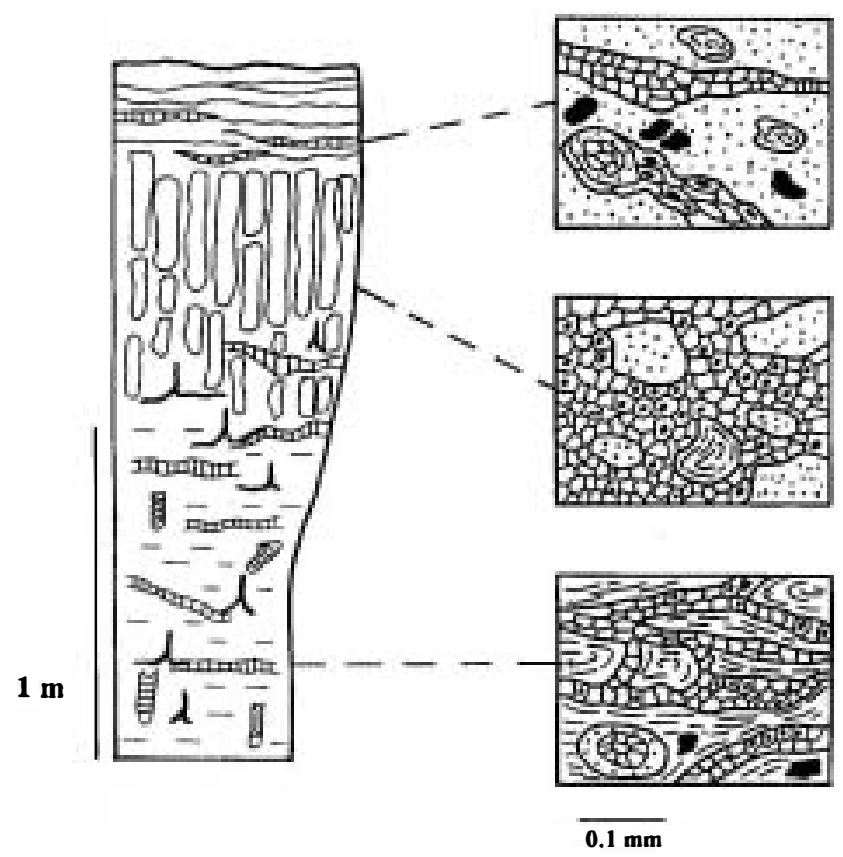

\section{LEGEND}

\begin{tabular}{|c|c|}
\hline$\approx$ & Platy Horizon \\
\hline ondo & Prismatic horizon \\
\hline 䡒 & Bioturbation \\
\hline & Rhizoliths \\
\hline 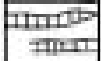 & Calcite/Dolomite veins \\
\hline-- & Clays \\
\hline
\end{tabular}

\begin{tabular}{|c|c|}
\hline (23) & Clay-Glaebules \\
\hline & Micrite \\
\hline & Floating and etched detrital grains \\
\hline & $\begin{array}{l}\text { Micro/pseudospar mosaics. } \\
\text { Some of the crystals show a dark nucleus }\end{array}$ \\
\hline
\end{tabular}

Fig. 4. Sketch of a complete calcrete profile showing the three horizons that have been typically differentiated: lower bioturbated clays. prismatic and platy. The most characteristic microfabrics of each horizon are sketched at the right of the profile.

and micro-pseudospar, although some clay infills are also recognized. These root traces occur all along the calcrete profiles, but they are more prominent in the lowermost horizons. Calcite and/or dolomite crystals forming microspar and pseudospar mosaics are present filling cracks in white veins widely distributed within the lower clays (Fig. 3A). The veins, which are also present in the platy horizon, are mostly horizontal. They are up to $5 \mathrm{~mm}$ in width and the length is more variable, reaching up to several decimetres. The veins show different patterns from relatively regular and straight to highly sinuous. They were originally desiccation cracks later enlarged by root penetration. The prismatic horizon, $0.2-0.8 \mathrm{~m}$ thick, sharply overlies these clays (Fig. 3B). The prisms are highly elongated and show lengths up to $0.4 \mathrm{~m}$ and widths average $60 \mathrm{~mm}$. The horizon is formed by a relatively dense mosaic of microspar and pseudospar in which some floating and etched detrital grains (quartz and feldspars) and some clay aggregates occur (Fig. 4). The mosaics occur in centimetre-size nodules surrounded by clays. This horizon is sharply overlain by a platy one up to 0.6 $\mathrm{m}$ thick (Fig. 3C). In the platy horizon the laminae are very irregular and sometimes very discontinuous (Fig. 3C). They are a few centimetres thick. The laminae are formed by dense micrite which also shows floating detrital grains and some clay aggregates. The micrite is disrupted by veins that are filled with microspar and pseudospar mosaics (Fig. 4), similar to those described in the lower clays.

\section{Petrography}

The microspar and pseudospar mosaics occur in two ways within the calcrete-dolocrete profiles.

(1) In the prismatic horizons (Fig. 4), the crystalline microfabrics occur as massive mosaics of calcite and/or dolomite crystals that form irregular, centimetre size, nodules, well differentiated from the soil matrix by their lighter colour and their crystalline fabric (Fig. 5).

(2) Within the lowermost part or the profiles, as well as in the platy horizon, they occur within veins (see description above) distributed irregularly in the calcrete-dolocrete profiles (Fig. 6). The arrangement of the crystals within the veins is not homogeneous. Sections normal to the veins show distinct concentric 

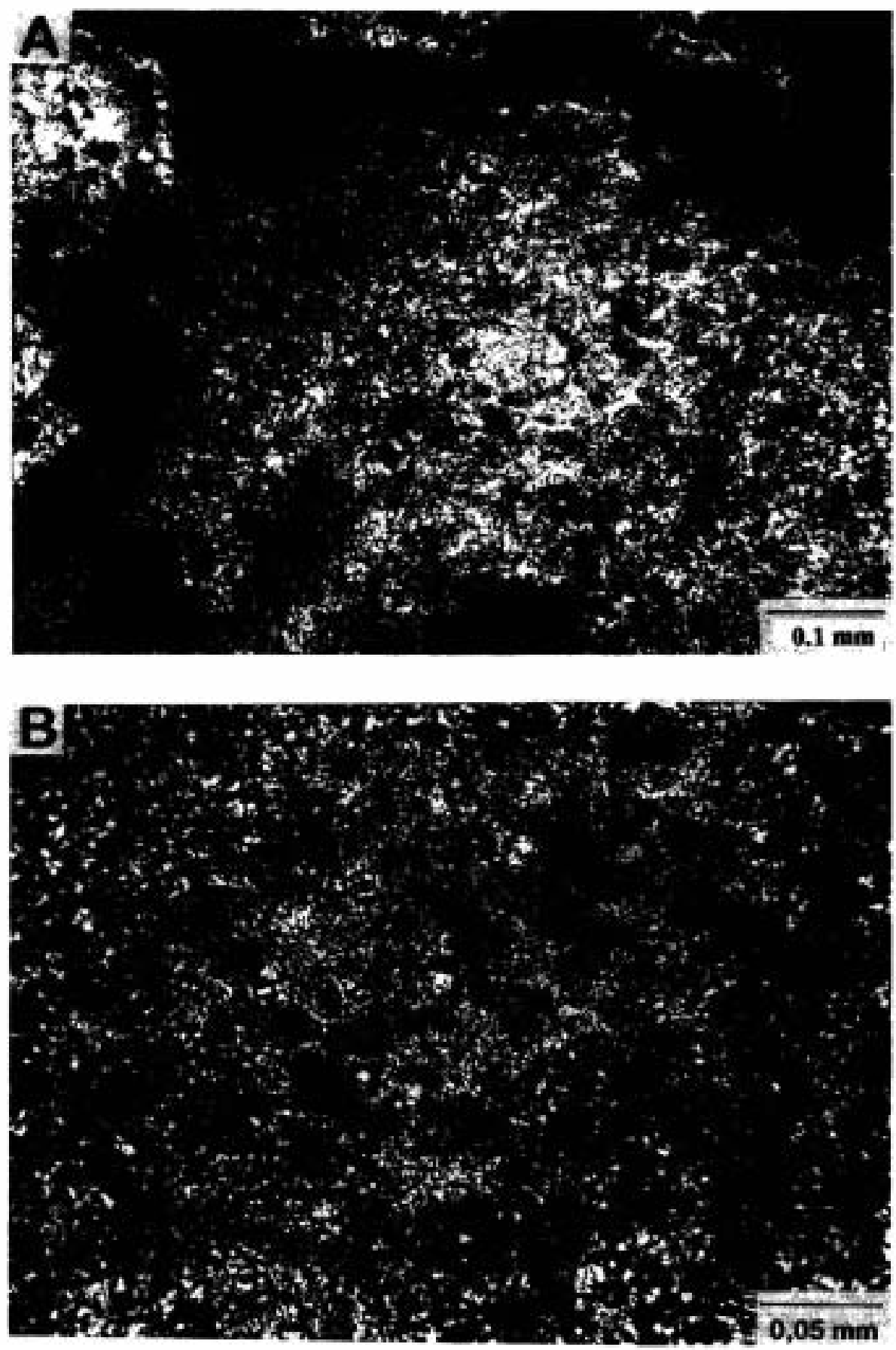

Fig. 5. Photomicrographs of the calcrete-dolocrete microfabrics. (A) View of the internal texture of a nodule within the prismatic horizon. It is formed by dolomite crystals of about $20 \mu \mathrm{m}$ size. (B) Close-up view of the microspar and pseudospar mosaics. Many of the crystals have a dark nucleus and a lighter crystalline cortex, in this case of dolomite. 

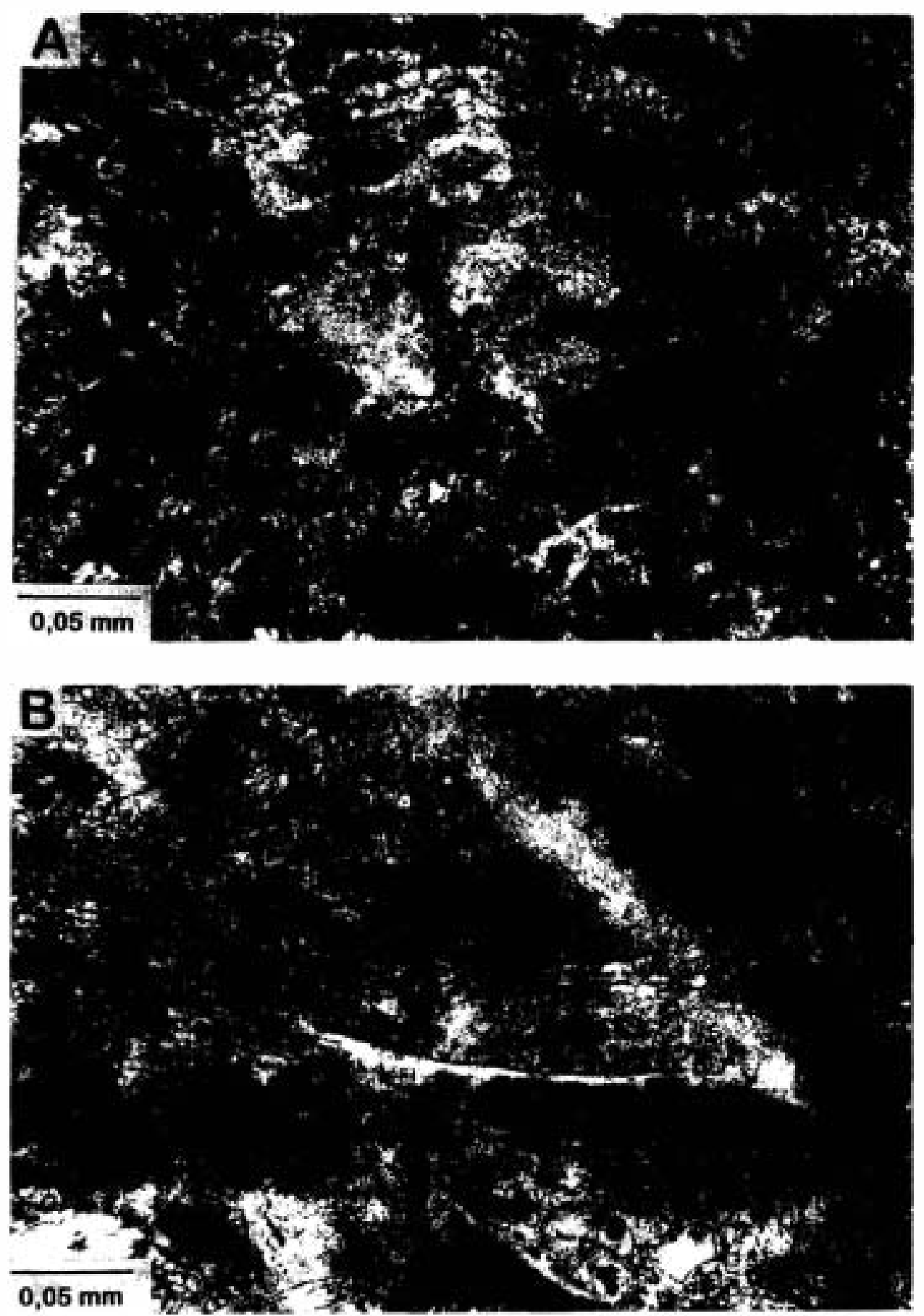

Fig. 6. Photomicrographs of the veins filled by the crystalline mosaics. (A) Cross-section (?) of a white vein showing a vague circular pattern of crystal arrangement. Most of the crystals show a black nucleus. (B) Longitudinal section of a white vein formed by elongated calcite crystals. 

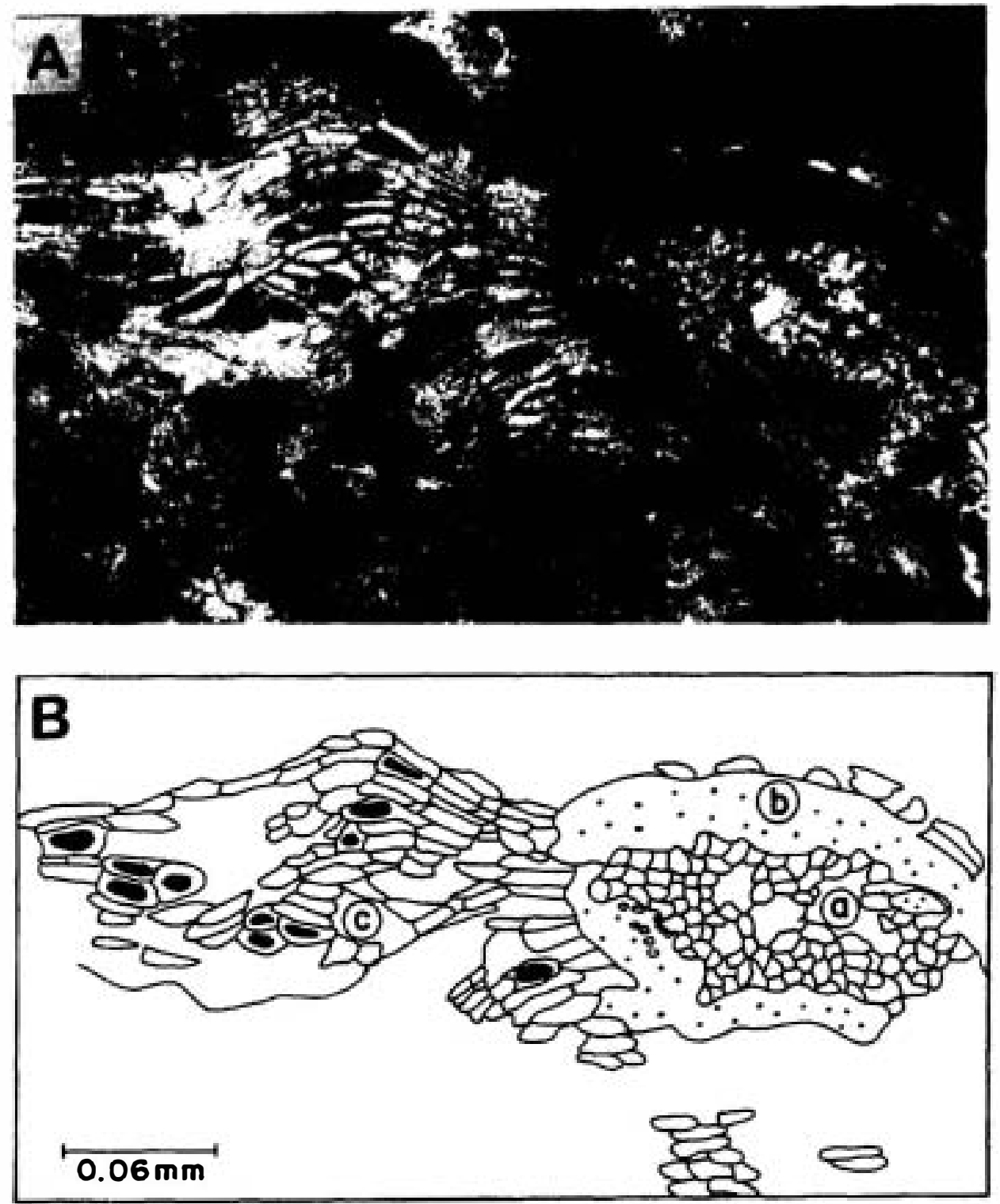

Fig. 7. (A) Ph tomicrograph of a vein in which the arrangement of the crystals is clearly observed. View is almost oblique. (B) Sketch of (A). The inner zone $(a)$ is formed by a more or less equigranular mosaic of calcite crystals which are thought to correspond to calcified parenchymatic cells or xylem vessels. Zone $(b)$ is formed by dark micrite which may correspond to the endodermis. Zone $(c)$ consists of elongated calcite crystals that are interpreted to have been formed in the outer part of the root. See Fig. 10 for comparison with the internal structure of a living root.

zones (Fig. 7). In the inner zone (zone a) the crystals are isodiametric, and most of them do not show any microporosity. Zone $b$ is darker and thinner and is formed of a ring of micrite. The outer zone (zone c) is formed by elongated crystals whose nuclei are black although in some cases there are no nuclei and a central void can be recognized in the inner part of the crystals. Mineralogy is not relevant with respect to size and morphology of the crystals, as size and morphology depend on the position the 
crystals occupy within the vein, indicating that the primary fabric is preserved. Dolomite rhomboids and coarse dolomite crystals are not present in the dolocretes.

An overall view of the mosaics throughout the profiles shows that the crystals present different textures. Some of them consist of an outer and lighter area of calcite and/or dolomite that encloses either a dark nucleus or a central pore. The crystals located in zone (a) of the veins or in some areas of the massive nodules are formed by dense and non-porous calcite and/or dolomite (Figs. 5-7). All the crystals show uniform extinction. Cathodoluminescence analyses reveal that in all cases their nuclei are non-luminescent, but the cortex luminesces brightly. Crystal size varies from 15 to $35 \mu \mathrm{m}$.

Backscattered images show that the crystals are isodiametric although their morphology varies from rounded to more or less polygonal (Fig. 8A,B). They are formed by a cortex and a central part, usually porous (Fig. 8B). SEM images show that the crystals are arranged as honeycomb-like structures (Fig. 8C). The boundaries between the different crystals are more clearly shown in the backscattered images (Fig. 8B). Some irregular biotic morphologies can be recognized occasionally bordering the crystals and in the intercrystalline microporosity (Fig. 8D,F). Silica sphelurites (Fig. 8E) also occur in the microporosity.

\section{Stable isotope geochemistry}

Due to the small size of the crystals, which makes it very difficult to separate them from the rest of the sample, oxygen and carbon isotope analyses have been carried out on the whole sample, not specifically on the mosaics. The samples were obtained by drilling from pre-selected areas and analysed on a SIRA analyser following reaction with $100 \%$ phosphoric acid. The isotopic values (Fig. 9) are higher in dolocretes in which the crystals are mainly dolomite (mean $\delta^{13} \mathrm{C}$ about $-6.5 \%$ and $\delta^{18} \mathrm{O}-5.1 \%$ PDB), than in calcretes (mean values are $-10.1 \%$ ofor $\delta^{13} \mathrm{C}$ and $-7.9 \%$ o PDB for $\delta^{18} \mathrm{O}$ ).

\section{Interpretation and discussion}

The microspar and pseudospar mosaics do not resemble typical products of recrystallization or dolomitization of precursor carbonate crystals. Whereas recrystallization microspar and pseudospar mosaics show features such as irregular or curved intercrystalline boundaries, very irregular crystal size distribution, and gradational boundaries with the host rock (Bathurst, 1975; Tucker, 1991), such features are absent in the calcretes--dolocretes analysed here.

The arrangement of microspar and pseudospar mosaics within the veins as well as their presence in rhizoliths strongly suggest that the crystals were formed in relation to root activity and represent calcified roots. These veins are similar to the sheets and stringers described by Wright et al. (1995) in rhizolite calcretes from the Cameros Basin. The arrangement of the crystals within the veins, the isodiametric morphology of the crystals, their size (between 15 and $35 \mu \mathrm{m}$ ), and the relative size of outer cortex and nuclei of the crystals may indicate that the crystals correspond to calcified cells of roots. The dimensions of the crystals are in the same range as that recognized in living roots, which are about 35 $\mu \mathrm{m}$ across for the whole cell (Raven et al., 1991). Moreover, the size of the outer cortex of the crystals in relation to the central pore (see discussion below) is compatible with the size of a thickened cell wall. In living roots, cell walls are about $0.5-2 \mu \mathrm{m}$ in thickness.

Occurrences of microspar and pseudospar mosaics associated with roots are not uncommon. They have been recognized in the Pleistocene eolianite deposits of Mallorca in which the mosaics occupy the innermost part of rhizocretions (Calvet et al., 1975). In other cases the mosaics seem to occupy the whole root, such as in soils developed on Quaternary terraces of the Tajo River (Roquero, 1994) or in the Upper Miocene of the Madrid Basin where the mosaics fill root tubes within palustrine limestones (Sanz, 1994).

As described previously, the crystals within the veins are concentrically arranged in distinct, more or less regular zones (Fig. 7), very similar to sections of living roots (Fig. 10). Within the inner part (zone a) the crystals do not show any porosity and their location suggests that they very probably represent either parenchymatic cells or xylem vessels (or both). The micritic ring which envelopes the inner part of the root (zone b) may correspond to the endodermis. In the external parts of the root most of the 


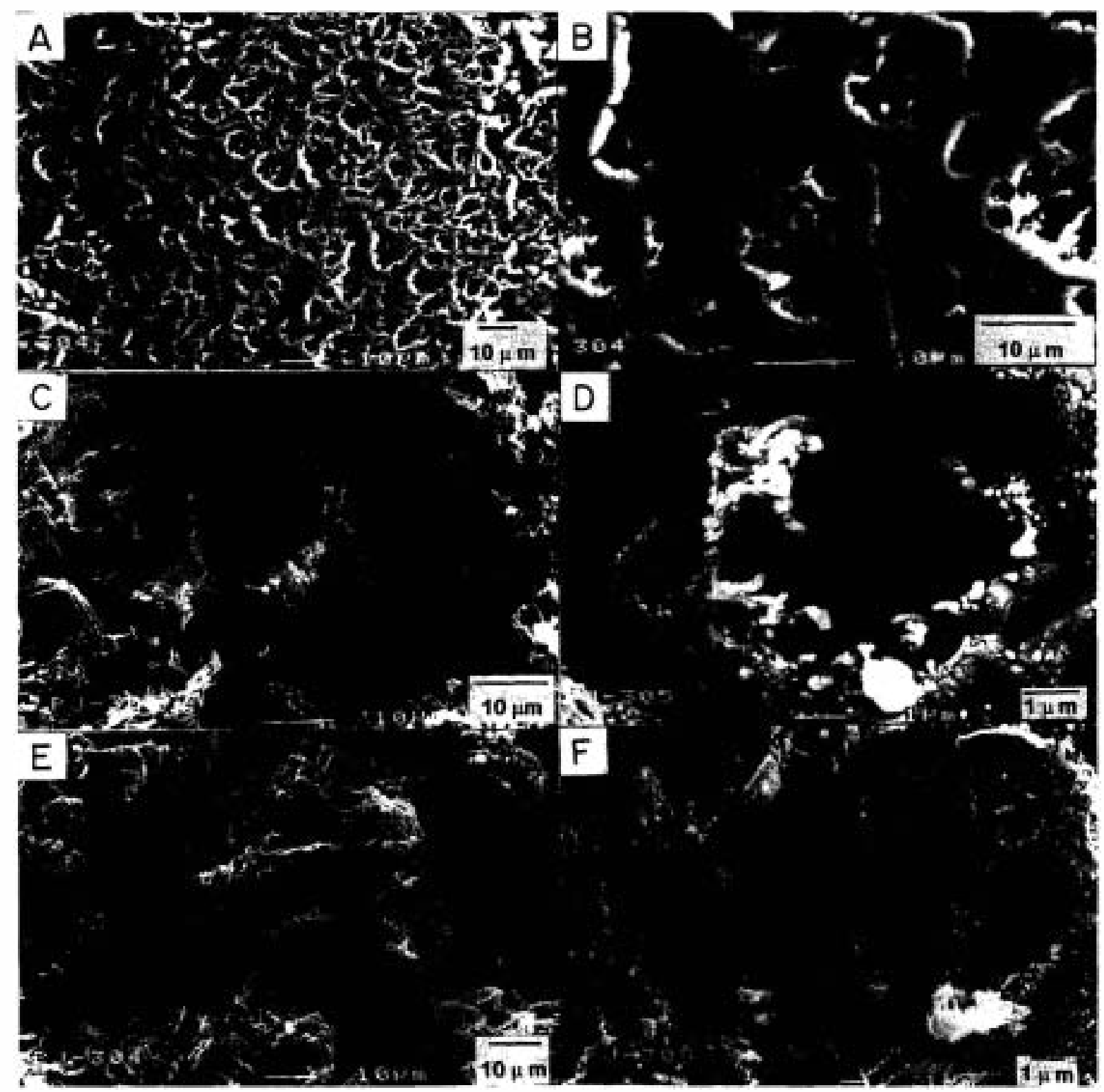

Fig. 8. Scanning electron microscope images. (A) General view of the microspar and pseudospar mosaics seen as a backscattered electron image. (B) Close-up view of (A) showing variation of the crystal morphologies. Note that the nuclei of the crystals are empty whereas the cortices are formed by calcite. (C) SEM image showing the honeycomb arrangement of the crystals, in this case of dolomite, which are formed by a crystalline cortex and a central pore. (D) Close view of a single crystal. Some organic structures, probably fungi, border the cortices of the crystals in the inner part of the walls. (E) Some silica spherulites occur in the innermost part of the crystal, in this case formed of dolomite. (F) Drganic filaments occupy the central pore of the crystal.

crystals show internal microporosity, indicating that calcification was of the cell walls.

From this point of view, the fabric of the mosaics is a well preserved primary fabric in which the size and arrangement of the crystals is controlled by the morphology and activity of the root. The distribution of the calcified cells in the root is related to different ionic environments within the active root system. In 


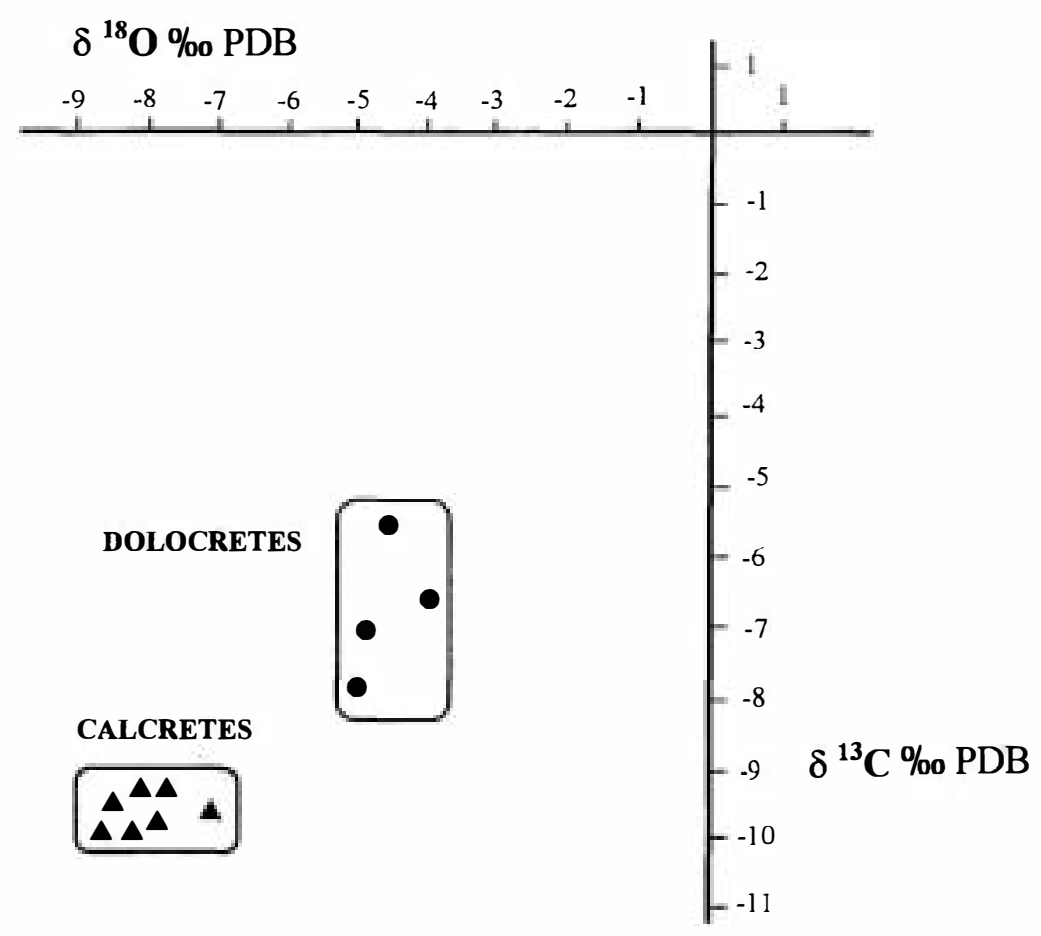

Fig. 9. $\delta^{13} \mathrm{C}-\delta^{18} \mathrm{O}$ cross-plot of some of the calcrete-dolocrete samples.

the outer part (root cortex) the cells are in the same ionic microenvironment as in the soil, whereas in the inner part the ionic conditions are mostly controlled by cellular activity that may favour the selective input of $\mathrm{Ca}^{2+}$, enabling calcification of the cells in this inner part of the living root.

The biogenic origin of this system is also confirmed by the isotopic data. The exact composition of the crystals is not known, but the overall $\delta^{18} \mathrm{O}$ and $\delta^{13} \mathrm{C}$ values of the samples are very low (Fig. 9), indicating the influence of light meteoric waters as well as the organic carbon from the soil organic matter (Wright and Alonso Zarza, 1992). The low values are very close to the absolute limit of $\delta^{13} \mathrm{C}$ in soil carbonates, is -12 to $-13 \%$ o PDB (Cerling, 1984; Burns and Rossinsky, 1989). These values are expected in the most favourable conditions for maximum ${ }^{13} \mathrm{C}$ depletion, which are: $100 \%$ of $\mathrm{C}-3$ flora, lack of input of atmospheric $\mathrm{CO}_{2}$, and no influence of higher carbon values from pre-existing carbonates. According to the low isotopic values, the soil carbonate was not only precipitated by physico-chemical mechanisms or evapotranspiration (Cerling, 1984), but biogenic processes did contribute to the formation of the crystals. Moreover, these values are in the same range as obtained by J.Ch. Fontes (in Bodergat, 1974 and Morin, 1993). The latter author analysed the isotopic composition of different types of ancient Microcodium as well as recent calcified roots from a wide variety of localities in France.

Calcification seems to be a common phenomenon in, or on, many aquatic (Borowitzka, 1984) and nonaquatic plants (Jaillard, 1987). The biogenic precipitation of $\mathrm{CaCO}_{3}$ is the result of metabolism and its effect on the physico-chemical process of $\mathrm{CaCO}_{3}$ nucleation and precipitation (Borowitzka, 1984). In aquatic plants, calcite formation may be intracellular, intercellular, or wholly extracellular (Borowitzka, 1984). In non-aquatic plants, calcification can be intracellular, such as in the roots of rape (Jaillard, 1987), or around the cell walls (Dupuis et al., 1986). The deposition of $\mathrm{CaCO}_{3}$ on the cell wall is favoured, according to Borowitzka (1984), by: (a) the polysaccharide component of cell walls that may influence isomorphism of calcite crystals, suggesting that the cell acts as an epitaxial substratum for 


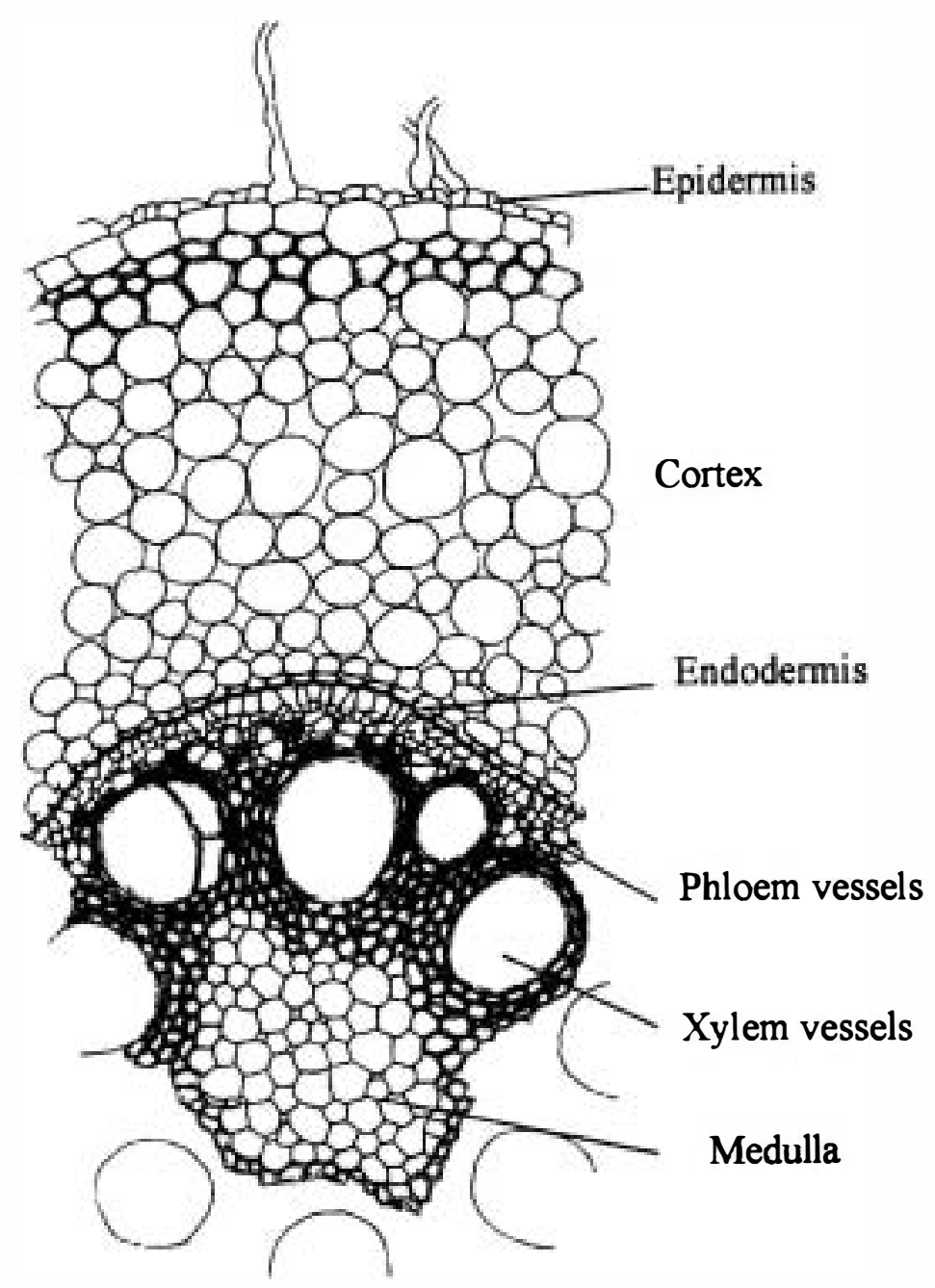

Fig. 10. Sketch showing the main elements that are commonly observed in a living root of Mococotyledones that generally only have primary growth. The arrangements of the xylem vessels may be concentric as in the sketch or may be following different distributions that vary between speciess or even within the same plant. (Modified from Bracegirdle and Milnes, 1982.)

crystallization; and (b) the presence of a charged surface may be sufficient to induce 'heterogeneous' nucleation, which may be due to the surface charge of the cell wall or to the selectivity of the cell wall for $\mathrm{Ca}^{2+}$ over $\mathrm{Mg}^{2+}$. Biomineralization of root cells by calcite requires the availability of $\mathrm{Ca}^{2+}$ and a favourable $\mathrm{pH}$ to enable calcite precipitation. $\mathrm{Ca}^{2+}$ is taken by roots from the soil, where it may come from weathered plagioclase or from ground water. Calcium concentration is usually very low in the cytoplasm of the cell but it is needed to stabilize cell walls and plasma membranes, so most of the calcium is retained on the cell walls (Clarkson, 1984; Kirkby and Pilbeam, 1984). A different process takes place when the whole cell is calcified, which implies an intracellular crystallization of calcite within the vacuoles of the cortical cells of roots (Jaillard, 1987). The favourable $\mathrm{pH}$ is produced by the biochemical changes occurring in the soil or specifically in the rhizosphere due to root activity (Klappa, 1980) and by the palaeoenvironmental setting. Occurrence of sepiolite and $\mathrm{Mg}$-smectites within the palaeosols and in the nearby lake margin confirm that the environment was slightly alkaline, favouring the precipita- 


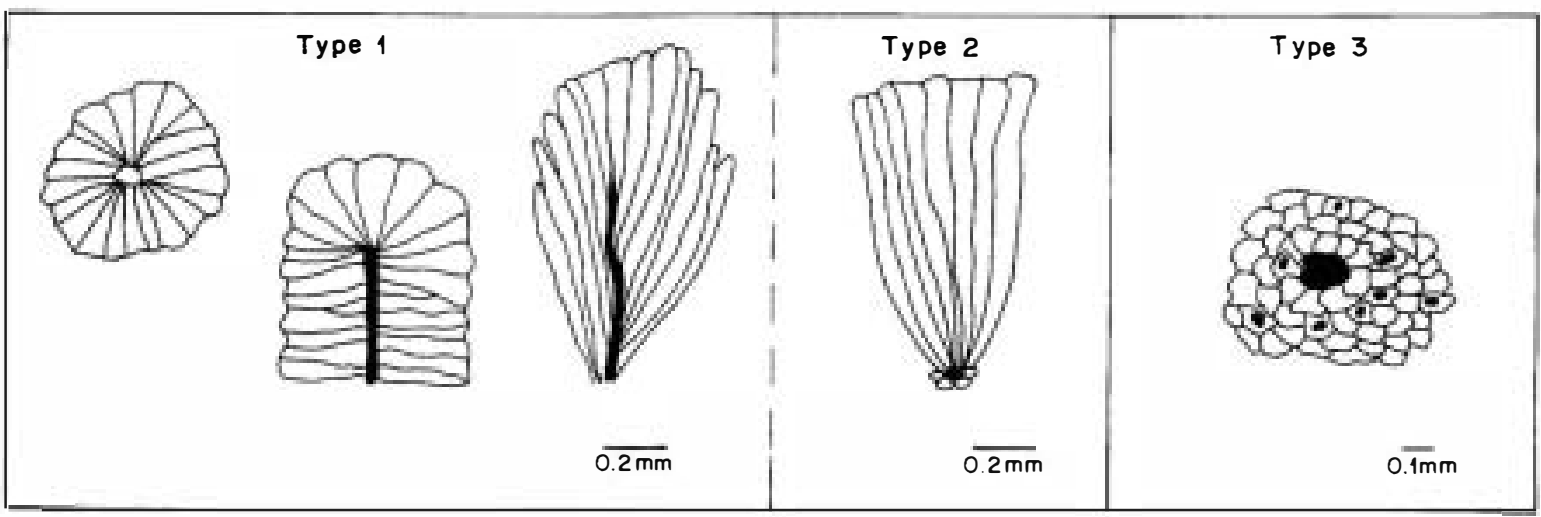

Fig. 11. Sketch of main Microcodium types. Modified from Bodergat (1974) and Plaziat (1984). Note that type 3 shows strong similarities with microspar and pseudospar mosaics described in this paper.

tion of calcite (Calvo et al., 1986; Alonso Zarza et al., 1992).

The fact that the root cells are preserved in calcite and also in dolomite needs some comment. It is necessary to take into account that there is no record of organisms that biomineralized dolomite (Lowenstam, 1981), which suggests replacement of the calcified cells by dolomite. Dolomitization can easily be produced in these $\mathrm{Mg}$-rich environments by diagenesis in contact with ground water from the adjacent lake environment (Calvo et al., 1995). Dolomitization is interpreted as a very early process as indicated by the preservation of the primary fabric and by the relatively small differences in the isotopic composition of both calcretes and dolocretes. These differences are related to the isotopic fractionation involved in the precipitation of dolomite (Northrop and Clayton, 1966), but also to the slightly more saline ground waters which probably caused dolomitization. The fact that the primary morphology of the cell is preserved also in dolomite indicates that dolomite crystals faithfully pseudomorphed the cells. Dolomitization with good preservation of the original calcitic or aragonitic fabrics is common in high-Mg calcite precursor grains (Bullen and Sibley, 1984) or in early dolomitization processes as described in modem supratidal dolomites (Shinn, 1983). Very early dolomitization occurring on the lake mudflats (Calvo et al., 1995) allowed the preservation of the primary fabric of the root cell crystals.

Calcified root cell structures have been often described in the sedimentological literature (Klappa,
1978; Goldstein, 1988); however, a close relationship between these structures and the so-called $\mathrm{Mi}$ crocodium has been seldom established. The elucidation of Microcodium has been the aim of many papers during the last 25 years (Esteban, 1972, 1974; Bodergat, 1974; Klappa, 1978; amongst others). Much of the work has been focused on classical or typical Microcodium, such as Microcodium (a) of Esteban (1972) or types 1 and 2 of Plaziat (1984) (Fig. 11). Type 1 consists of prismatic calcite crystals arranged either perpendicular or inclined to a central channel. Type 2 is formed by prisms bunched together around one side of the central channel or axis of progression. The mosaics recognized in some palaeosols of the Madrid Basin clearly resemble $\mathrm{Mi}$ crocodium (b) of Esteban (1972) or type 3 of Plaziat (1984) in which isodiametric crystals are arranged irregularly around a central void (Fig. 11).

Colonial bacteria have been considered responsible for Microcodium (Lucas and Montenat, 1967), whereas Plaziat (1984) points to bacteria and/or fungi as the organisms that create this structure. Microcodium has been described very commonly in relation to roots (Klappa, 1978; Arribas et al., 1996; amongst others). Our study allows a new interpretation involving the origin of Microcodium (type b) of Esteban, 1972) in roots. It differs from the interpretation of Klappa (1978, 1980), who suggested that some forms of Microcodium result from the calcification of a symbiotic association between fungi and cortical cells of roots. In the palaeosols of the Madrid Basin, the size and the arrangement of the 
crystals within the roots (Fig. 7) indicate that the calcification took place in the root cortex but also, even more prominently, in the innermost part of the root. This suggests that the crystals are formed by processes affecting the internal part of the root, so that Mycorrhizae should not be considered to play a role. In the cortex of the root the cells are not completely calcified, but, preferably, the wall cells are calcified, which is in contrast with the results obtained by previous authors (Klappa, 1978; Jaillard, 1987; Jaillard et al.. 1991) who recognized cortical cells of roots totally calcified.

We do not have much data about the plant type responsible for these structures, only the root is preserved. Palaeogeographic data of the areas in which Microcodium (b) (Esteban, 1972) has been described indicate plants of a semiarid zone type similar to a present-day Mediterranean-type vegetation (Calvet et al., 1991). However, the presence of silica spherulites could indicate Graminae, as suggested by Jaillard (1983).

The Miocene root cell structures of the Madrid Basin that we have considered as Microcodium (b) provide evidence that this type of structure may be older than has been usually considered and suggests that Microcodium (b) may be found in strata of various ages and not only in Quaternary deposits. This is in agreement with the observations of Goldstein (1988), who described similar structures in Carboniferous strata. Occurrences of these crystals forming massive microspar and pseudospar mosaics may make their identification difficult and these structures could have been misinterpreted as neomorphic fabrics. This may be the case for some microspar mosaics which are commonly recognized in calcretes, especially in biogenic or 'Beta' calcretes (Wright, 1990). In some cases, the microspar and pseudospar mosaics may not simply be a neomorphic product but evidence for the presence of rooted vegetation.

\section{Summary and conclusions}

The Miocene palaeosols of the Madrid Basin contain microspar and pseudospar mosaics formed as the result of calcification of root cell structures as indicated by the arrangement, morphology, and size of the crystals. Moreover, isotopic data support the interpretation that they formed within soils. The petrographic data indicate that neither the whole root nor the whole cell were completely calcified. Within the root, the inner parts are totally calcified whereas the external parts are partially calcified; within the cells the cell walls were always calcified, whereas the cell protoplasts occur only calcified in the inner part of the root. Calcification of the cells took place in a favourable microenvironment caused by biochemical phenomena associated with plant activity, and was likely favoured by the charged surface of the cell wall together with the fact that polysaccharide components of the wall induce epitaxial growth of calcite.

These mosaics are considered to be a form of Microcodium because of the similarities they show with Microcodium (b) of Esteban (1972) or type 3 of Plaziat (1984). Our study points out, like those of previous authors, that this type of Microcodium is a structure related to the calcification of roots and can contribute significantly to the formation of rhizolite calcretes.

Finally, our observations show that microspar and pseudospar mosaics resulting from root cell calcification may have a high preservation potential, even if they have been dolomitized. These microfabrics should be considered a typical biogenic feature, and probably some of the microspar which occurs in relation to pedogenic fabrics, such as in some laminar calcretes, may have this origin.

\section{Acknowledgements}

The manuscript has considerably benefited from discussions with V.P. Wright, G.J. Retallack, B. Jones, E. Verrecchia, H.C. Monger, H.S. Chafetz and comments by an anonymous referee. The work has been supported by DGICYT through project PB-95 0114.

\section{References}

Alonso, A.M., Calvo, J.P., García del Cura, M.A., 1986. Sedimentología y petrología de los abanicos aluviales y facies adyacentes en el Neógeno de Paracuellos de Jarama (Madrid). Estud. Geol. 42, 79-101.

Alonso Zarza, A.M., Wright, V.P., Calvo, J.P., García del Cura, M.A., 1992. Soil-landscape and climatic relationships in the Middle Miocene of the Madrid Basin. Sedimentology 39, 1735 . 
Arribas, M.E., Estrada, R., Obrador, A., Rampone, G., 1996. Distribución y ordenación de Microcodium en la Formación Tremp: anticlinal de Campllong (Pirineos Orientales. provincia de Barcelona). Rev. Soc. Geol. Esp. 9, 9-18.

Bathurst, R.G.C., 1975. Carbonate Sediments and Their Diagenesis. Elsevier, Amsterdam, 658 pp.

Bodergat, A.M., 1974. Les Microcodiums: milieux et modes de developpement. Thèse, Documents du Laboratoire de Géologie de la Faculté des Sciences de Lyon, 62, pp. 137-235.

Borowitzka, M.A., 1984. Calcification in aquatic plants. Plant, Cell Environ. 7, 457-466.

Bracegirdle, B., Milnes, P.H., 1982. Atlas de Estructura Vegetal. Editorial Paraninfo, Madrid, 123 pp.

Bullen, S.B., Sibley, D.F., 1984. Dolomite selectivity and mimic replacement. Geology 12, 655-658.

Burns, S.J., Rossinsky, V.Jr., 1989. Late Pleistocene mixing zone dolomitization, southeastern Barbados, West Indies - Discussion. Sedimentology 36, 1135-1142.

Calvet, F., Pomar, L., Esteban, M., 1975. Las rizocreciones del Pleistoceno de Mallorca . Rev. Inst. Invest. Geol. Univ. Barcelona 30, 35-60.

Calvet, F., Wright. V.P., Giménez, J., 1991. Microcodium: descripción y origen. Implicaciones paleogeográficas y paleogeomorfológicas. Comunicaciones I Congreso del Grupo Español del Terciario, Vic, pp. 50-51.

Calvo, J.P., Alonso Zarza, A.M., García del Cura, M.A., 1986. Depositional sedimentary controls on sepiolite occurrences in Paracuellos de Jarama, Madrid Basin. Geogaceta 1, 25-28.

Calvo, J.P., Alonso Zarza, A.M., García del Cura, M.A., 1989. Models of Miocene marginal lacustrine sedimentation in response to varied depositional regimes and source areas in the Madrid Basin (central Spain). Palaeogeogr. Palaeoclimatol. Palaeoecol. 70, 199-214.

Calvo, J.P., Jones, B.F., Bustillo, M., Fort, R., Alonso Zarza, A.M., Kendall, C., 1995. Sedimentology and geochemistry of carbonates from lacustrine sequences in the Madrid Basin, Central Spain. Chem. Geol. 123, 173-191.

Cerling, T.E., 1984. The stable isotopic composition of modern soil carbonate and its relationships to climate. Earth Planet. Sci. Lett. 71, 229-240.

Clarkson, D.T., 1984. Calcium transport between tissues and its distribution in the plant. Plant, Cell Environ. 7, 449-456.

Ducloux, J.. Butel, P., 1983. Micromorphology of calcretes in a slope deposit in the Poitevine Plain, France. In: Bullock, P., Murphy, C.P. (Eds.), Soil Micromorphology. Kluwer, Dordrecht, Vol. 2, pp. 537-646.

Dupuis, C., Gaudant, J., Perreau, M., Riveline, J., Willems, W.. 1986. Sables thanétiens et faciès sparnaciens du N. du bassin de Paris à Lihons (Somme). Données paléontologiques, interprétations stratigraphiques et paléogéographiques. Bull. Inf. Geol. Bassin Paris 23, 43-58.

Esteban, M., 1972. Una nueva forma de prismas de Microcodium elegans Glück 1912 y su relación con el caliche del Eoceno Inferior, Marmellá, provincia de Tarragona (España). Rev. Inst. Invest. Geol. Univ. Barcelona 27, 65-81.

Esteban, M., 1974. Caliche textures and 'Microcodium' . Boll. Soc. Geol. Ital. 92 ((suppl. 1973)), 105-125.
Goldstein. R.H., 1988. Paleosols of Late Pennsylvanian cyclic strata New Mexico. Sedimentology 35, 777-803.

Gunatilaka, A., 1989. Spheroidal dolomites - origin by hydrocarbon seepage?. Sedimentology 36, 701-710.

Jaillard, B., 1983. Mise en évidence de la calcitisation des cellules corticales de racines de Graminées en milieu carbonaté. C. R. Acad. Sci. Paris 297, Sér. II, 293-296.

Jaillard, B., 1987. Les structures rhizomorphes calcaires: Modèle de réorganisation des minéraux du sol par les racines. Thèse, Univ. des Sciences et Techniques du Languedoc, Montpellier. 220 pp.

Jaillard, B., Guyon, A., Maurin, A.F., 1991. Structure and composition of calcified roots, and their identification in calcareous soils. Geoderma 50, 197-210.

Junco, F., Calvo, J.P., 1983. Cuenca de Madrid. In: Libro Jubilar J.M. Ríos, 2, Instituto Geológico y Minero de España (Ed.), Geología de España, Madrid, pp. 534-543.

Kirkby, E.A., Pilbeam, D.J., 1984. Calcium as a plant nutrient. Plant Cell Environ. 7, 397-405.

Klappa, C.F., 1978. Biolithogenesis of Microcodium: elucidation. Sedimentology 25, 489-522.

Klappa, C.F., 1980. Rhizoliths in terrestrial carbonates: classification, recognition, genesis and significance. Sedimentology 27, 613-629.

Lowenstam, A.H., 1981. Minerals formed by organisms. Science 211, 1126-1131.

Lucas, G., Montenat, C., 1967. Observations sur les structures internes et le développment des Microcodium. Bull. Soc. Géol. Fr. 9 (7), 909-918

Morin, N., 1993. Les Microcodium: architecture, structure et composition, comparaison avec les racines calcifiées. Thèse, Univ. des Sciences et Techniques du Languedoc, $132 \mathrm{pp}$.

Northrop, D.A., Clayton, R.N., 1966. Oxygen isotope fractionation in systems containing dolomite. J. Geol. 74, 174-196.

Plaziat, J.C., 1984. Le problème des Microcodium: une mise au point. In: Le Domain pyrénéen de la Fin du Crétacé à la Fin de l'Eocène: Stratigraphie. Paléoenvironnements et Évolution paléogéographique. Thèse, Université Paris-Sud II, pp. 637662.

Raven, P.H., Evert, R.F., Eichhom, S.E., 1991. Biología de las Plantas. Editorial Reverté, Barcelona, 773 pp.

Retallack, G.J., 1990. Soils of the Past. An Introduction to Paleopedology. Unwin Hyman, London, 520 pp.

Roquero, E., 1994. Relación Suelos-Geomorfología en el sector centro-meridional de la Cuenca de Madrid. Tesis Doctoral, Univ. Complutense, Madrid, 500 pp.

Sanz, M.E., 1994. Sedimentología de las formaciones Neógenas del sur de la Cuenca de Madrid, con énfasis en los procesos kársticos y edáficos asociados a las rupturas sedimentarias del Plioceno. Tesis Doctoral, Univ. Complutense, Madrid, 333 pp.

Sanz, M.E., Alonso Zarza, A.M., Calvo, J.P., 1995. Carbonate pond deposits related to semi-arid alluvial systems. Examples from the Tertiary Madrid Basin, Spain. Sedimentology 42, 437-452.

Shinn, E.A., 1983. Tidal flat environment. In: Scholle, P.A., Bebout. D.G., Moore, C.H. (Eds.), Carbonate Depositional Environments. Mem. Am. Assoc. Pet. Geol. 33, 173-210. 
Spötl, Ch., Wright, V.P., 1992. Groundwater dolocretes from the Upper Triassic of the Paris Basin, France: a case study of an arid, continental diagenetic facies. Sedimentology 39, 11191137.

Tucker, M.E., 1991. Sedimentary Petrology. Blackwell, Oxford, 259 pp.

Verrecchia, E.P., Freytet, P., Verrecchia, K.E., Dumont, J.L., 1995. Spherulites in calcrete laminar crusts: biogenic $\mathrm{CaCO}_{3}$ precipitation as a major contributor to crust formation. J. Sediment. Res. A65, 690-700.

Verrecchia, E.P., Freytet, P., Verrecchia, K.E., Dumont, J.L., 1996. Spherulites in calcrete laminar crusts: biogenic $\mathrm{CaCO}_{3}$ precipitation as a ma.jor contributor to crust formation reply. J. Sediment. Res. 66. 1041-1044.

Wright, V.P., 1990. A micromorphological classification of fossil and recent calcic and petrocalcic microstructures. In: Douglas,
L.A. (Ed.), Soil Micromorphology: A Basic and Applied Science. Developments in Soil Science, 19, Elsevier, Amsterdam, pp. 401-407.

Wright, V.P., Alonso Zarza, A.M., 1992. Significado de la composición isotópica $\left(\delta^{13} \mathrm{C}\right.$ y $\left.\delta^{18} \mathrm{O}\right)$ en paleosuelos carbonatados. Mioceno de la Cuenca de Madrid. Geogaceta 11, 61-63.

Wright, V.P., Platt, N.H., Marriott, S.B., Beck, V.H., 1995. A classification of rhizogenic (root-formed) calcretes, with examples from the Upper Jurassic-Lower Cretaceous of Spain and Upper Cretaceous of southern France. Sediment. Geol. $100,143-158$.

Wright, V.P., Beck, V.H., Sanz-Montero, M.E., 1996. Spherulites in calcrete laminar crusts: biogenic $\mathrm{CaCO}_{3}$ precipitation as a major contributor to crust formation - discussion. J. Sediment. Res. 66, 1040-1041. 